\title{
ECONOMIC COSTS OF YOUTH UNEMPLOYMENT IN LATVIA
}

\author{
Liva Grinevica, Baiba Rivza \\ Latvia University of Agriculture \\ Liva_g2@inbox.lv
}

\begin{abstract}
In foreign studies Latvia is positioned as a 'depressive' region in the year 2030, which will have an insufficient population of young people. Thus, Latvia as a country with a business-friendly environment will not be able to be competitive relative to other European countries and the flow of investment will be at risk, as well as passed on other, more competitive and better developed regions in demographic terms (Grinevica et al., 2016). It is one of the main reasons to deal with the youth unemployment problem and to realize the actuality and consequences. Also, one of the EU's priorities of development is to reduce youth unemployment. National labour force surveys (Hoffman, 2011) show that since 2008 the youth unemployment rate has risen in all the EU countries (Hjūza \& Borbējs-Pece, 2012). The current economic instability in the context of youth's prospects and opportunities in the labour market is uncertain (Balan, 2014). Youth unemployment has also a negative effect on economic growth and productivity.

The aim of the paper is to identify the importance of unemployed youths and draw the society's attention to the consequences. The paper presents a brief analysis of importance of unemployment costs as well as the calculation of an economic loss from youth unemployment in Latvia. The result was calculated using Okun's Law concept.
\end{abstract}

Key words: youth into the labour market, costs of youth unemployment, Okun's Law, gross domestic product (GDP).

\section{Introduction}

Youth unemployment has created particular concerns because individuals who have become unemployed in the first years of their employment can become detrimental to the society. Youth who are unable to find a job after completing education can be perceived as inefficient human capital with the possibility of deterioration in employment, which could contribute to an individual's social exclusion. At the same time, youth unemployment is problematic not only for the person being unemployed but also for the economy as a whole (Salvador \& Leiner-Killinger, 2008).

The transition from education to making money is becoming increasingly problematic (Keep, 2012). Increasingly diverse youth (including those who have had good school results) do not obtain education or undergo training and are not in employment, the labour supply is lower, including proper jobs (as opposed to unskilled temporary jobs), and the skills of youth are not very much demanded by employers (Global Unemployment Trends..., 2010).

Youth unemployment makes serious consequences to young people's future as well as to the state's economic income.

Various authors in their studies discuss the unemployment impact on youth's future and the country's economic situation.

Authors Novak and Darmo believe that unemployment is considered as a broad macroeconomic problem that is associated with job absorption, the wasting of human resources, the performance of the labour market, the success of economic policies and even with the risk of inflationary pressures. Unemployment itself has hidden potential to become a significant and serious social problem of the society (Novak \& Darmo, 2015).

Blanchflower and Freeman have found that youth unemployment affects social exclusion and in the case of long-term inability of young people to find a job, it has negative consequences for future working lives in terms of lower incomes and wages (Fares \& Tiongson, 2007; O’Higgins, 2001).

The European Union(EU) is facing a new challenge oriented to the so-called 'lost generation' and solving the status of this generation in global aspect. The role of youth is undeniable and countries have to revise political positions related to the young generation because the discontent of youth can become a major force for changing political regimes. If there are no attempts to solve the problem of youth unemployment, we might expect economic and political instability in the EU in future, as well as globally (Novak \& Darmo, 2015).

Youth unemployment rates are generally much higher, even double or more than double than unemployment rates for all ages. As for the rate for the total population, the youth unemployment rate in the EU-28 sharply declined between 2005 and 2007, reaching its minimum value $(15.1 \%)$ in the first quarter of 2008. The economic crisis, however, severely hit the young. From the second quarter of 2008, the youth unemployment rate has taken an upward trend, peaking at $23.9 \%$ in the first quarter of 2013 , before receding to $18.7 \%$ at the end of 2016 (Unemployment Statistics, 2017).

Latvia had the highest youth unemployment among the three Baltic States in the year 2016, according to Eurostat. 
The Eurostat figures show that $17.3 \%$ of young people aged 15-24 years were jobless in Latvia in 2016, growing by 1 percentage point from 2015 .

In Lithuania, this rate was $14.5 \%$ in contrast to $16.3 \%$ a year ago, while in Estonia $13.4 \%$ of youngsters were unemployed, up 0.3 percentage points from 2015.

At the same time, the EU average for youth unemployment in 2013 was $18.7 \%$ of young people between 15 and 24 years of age, down 1.6 percentage points from 2015 (Youth unemployment in..., 2017).

As stated above, in foreign studies Latvia is mentioned as a region with an insufficient population in the year 2030, which is one of the main reasons why there is the need to identify the amount of losses from youth unemployment and find the way how to deal with it.

The paper's aim was not to solve all problems associated with youth unemployment. In this case, the authors would like to introduce readers to the youth unemployment problem, economic costs of youth unemployment and the calculation of economic losses from unemployed youth's in Latvia.

The main aim of the research is to calculate the lost GDP from youth unemployment in Latvia.

The following tasks are set to achieve the aim:

1. To describe the main trends in youth unemployment;

2. To evaluate the theoretical findings on economic costs of unemployment by different authors;

3. To calculate the lost GDP by using Okun's Law from youth unemployment in the period from 2008 to 2015 in Latvia.

Novelty of the research: the lost GDP due to youth unemployment in Latvia in the period from 2008 to 2015 was calculated.

\section{Materials and Methods}

Research methodology: the monographic and descriptive method, statistical research methods, the graphic method, synthesis and analysis, the logical construction method, Okun's Law concept using GDP calculations to calculate the lost GDP from youth unemployment in the period from 2008 to 2015 in Latvia.

Theoretical framework of the research: the research elaboration is based on other scientific researches and findings in the economic field, statistical information provided by the Central Statistical Bureau of Latvia and Eurostat.

\section{Results and Discussion}

Analysis of Unemployment

The crisis that hit Europe in 2008 significantly and constantly more affects youth: in August 2015, youth (including aged up to 25 years) unemployment in the EU-28 was $20.1 \%$, while the overall unemployment rate was $9.4 \%$. Youth unemployment is more than twice as high as unemployment among adults in the EU-28. In addition to the immediate impact of the crisis, the education system and labour market structural problems in the transition from school to work has become lengthy and complicated. Youth unemployment can leave a lasting negative impact. In addition to a higher risk of unemployment, youth are also at a higher risk of poverty and exclusion and encounter more health problems in the future. A report by the European Commission 'Communication from the Commission to the European Parliament, the Council of Europe, the European Economic and Social Committee and the Committee of the Regions' (2012) highlights that there is an urgent need for effective solutions for youth in their transition to employment (Komisijas pazinojums Eiropas..., 2012).

In Latvia, Figure 1 shows that in 2009 compared with 2008 the overall unemployment rate was 9.8 percentage points higher. In 2010, the overall unemployment rate reached the highest level (19.5\%), assessing the period of time from 2006 to 2015. In 2010 , both overall and for young people in the age groups of 15-29 years, the unemployment rate reached the highest values - among young people aged between $15-19$ years $-63 \%$, 20-24 years $-32.8 \%$, $25-29$ years $-21.2 \%$, exceeding the average overall unemployment rate. In 2015, unemployment in total has fallen by 0.9 percentage points compared with 2014. In 2015, the overall unemployment rate was $9.9 \%$, for young people aged $15-19$ years $-27.9 \%$, young people between $20-24$ years old $-15.1 \%$, and young people between $25-29$ years old $-10.6 \%$.

In 2016, youth unemployment aged 15-19 was fallen by 8.6 percentage points compared with 2015 . The overall unemployment rate was $9.6 \%$. Youth unemployment aged 20-24 increased by 2 percentage points $-17.1 \%$ compared with 2015 , for young people aged 25-29 increased by 0.2 percentage points $10.8 \%$ compared with 2015 .

\section{Economic costs of unemployed youth}

Unemployment leads to significant losses both for the unemployed and for society as a whole, the damage increases with the length of unemployment (Dao \& Loungani, 2010).

Costs of unemployed include loss of income, loss of skills and qualifications, negative impacts on health, etc. For society it is the fall in tax revenue and increases of fiscal cost are due to unemployment benefits, income inequality and poverty increase, weakening of social cohesion (e.g., less trust to the state power) and the loss of human capital. Structural unemployment causes (e.g., skills and geographical 


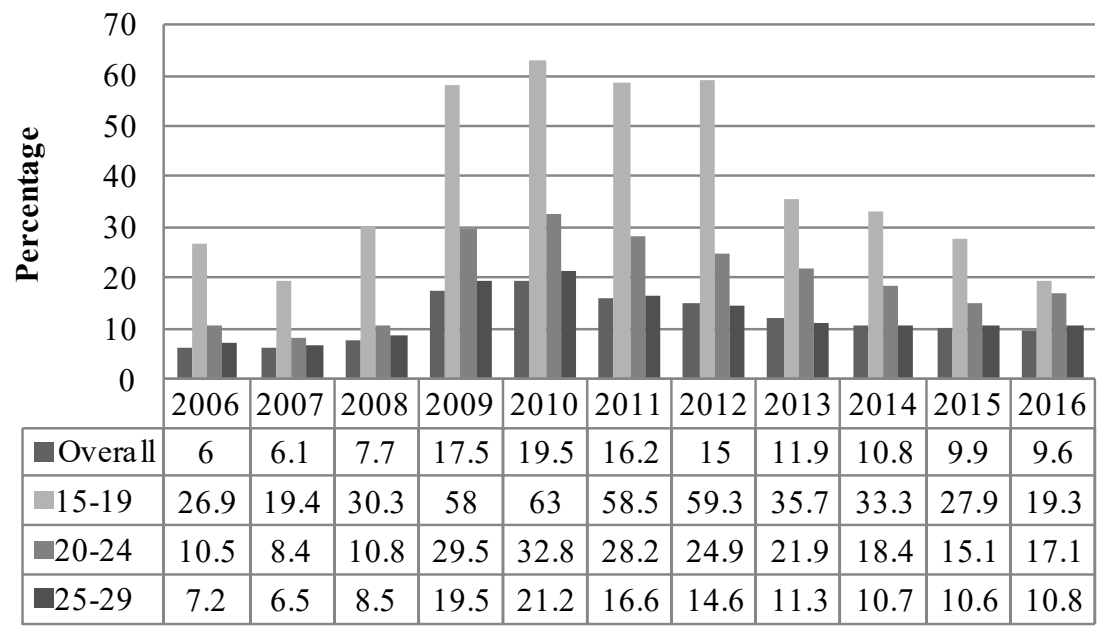

Source: data from the Central Statistical Bureau of Latvia.

Figure 1. Unemployment rate among young people for different age groups and overall in Latvia from 2006 to $2016(\%)$.

mobility) mismatch between labour supply and demand. One of the reasons is an ongoing price and wage rigidities. Unemployment creates significant losses to person and to the whole community (Augsts bezdarbs Latvijā...., 2010).

The costs of youth unemployment for individuals and the communities they live in is enormous. But youth unemployment also results in significant costs to the public purse. For all of the reasons above, youth unemployment translates into higher spending on benefits, lost income to the exchequer through tax receipts forgone, and higher spending on services such as the criminal justice system. For example, in England in 2012 research for the Commission found that youth unemployment is likely to cost the Exchequer approximately $£ 4.8$ billion (more than the 2011-2012 budget for further education for 16- to 19 -year-olds), and the wider economy $£ 10.7$ billion in lost output:

- the total benefit bill for youth unemployment at its current levels is likely to be just under $£$ 4.2 billion;

- the total cost of youth unemployment at its current levels in terms of taxes foregone is likely to be just over $£ 600$ million;

- the total cost to the economy of youth unemployment at its current levels in terms of lost output is likely to be $£ 10.7$ billion (Youth Unemployment: the..., 2012).

However, because youth unemployment has a negative impact on young people's future prospects, its costs include not just those current costs outlined above, but future costs too (Youth Unemployment: the..., 2012).

In 2010, the Swedbank experts estimated that in Latvia case emigration would have very painful consequences of structural unemployment. This would mean the increase of burden to the remaining labour force of Latvia, and the threat of social protection and the sustainability of the pension system - balance of the budget in such a case would be required in order to reduce social spending and/ or increase taxes. It might reduce the motivation to pay taxes and evasion of tax payment. Consequences of structural unemployment and emigration (especially highly skilled manpower drain) are slowdown of the potential impacts of economy. Labour resource is being depleted - if entrepreneurs want to increase production volume, they will be confronted with the labour shortages and the inability to find qualified employees (Augsts bezdarbs Latvijā...., 2010).

Losses for the state of unemployed young people can be approximated by calculating the unmanufactured volume of gross domestic product (GDP) (in the given year) by taking into account the proportion of the unemployed youth in number of employees.

The GDP is total volume of final products and services in the territory during the year. It is calculated using data of domestic production (at current and constant prices), expenditure (current and constant prices) and income (only current prices) (Iekšzemes kopprodukts Latvijā..., 2015).

Economic costs arise because economic resources are not fully exploited due to unemployment. The consequences are a decrease of the goods and services production, personal income and state budget revenues. However, the expenditure of the state budget is growing. Economic growth will be faster if employment will grow and unemployment will fall. However, in order to ensure a reduction of unemployment rate, it must comply with any other 
relevant relationship -economic growth rate must be greater than the growth rate of annual potential GDP. The decline in unemployment is possible when the real GDP annual growth rate is higher than the potential growth rate of GDP (studies have shown that it represents average 3\% per year). This means that real GDP will be greater than 3\% (Bikse, 2015).

Real GDP growth of $2 \%$ above potential GDP provides a reduction in the unemployment rate by $1 \%$. By contrast, real GDP decrease of $2 \%$ and increase unemployment level by $1 \%$ (Bikse, 2015).

If the actual unemployment rate compared with the previous year is constant, the real GDP growth rate is 3\% per year. The following GDP growth is provided with population growth, capital accumulation and technological progress. If the unemployment rate compared with the previous year will increase of $1 \%$, the real GDP will decrease per $2 \%$. The economic losses resulting from the cyclical unemployment is the additional production, which could produce every unemployed person if he was employed. Economists believe that because of unemployment or loses of unmanufactured actual output is the amount that should be produced to meet potential production if in the economy is natural unemployment. It shall be calculated as the difference between the potential GDP (which could produce) and real GDP - the actual output (the amount that is produced). In order to calculate the unmanufactured real GDP of unemployed, in the 1960s US economist Arthur Okun discovered the difference between the level of unemployment and the real GDP - 1:2 (Bikse, 2015).

The coherence between the level of unemployment and unmanufactured GDP is expressed with Okun's Law: if the actual unemployment rate exceeds the natural unemployment rate of $1 \%$, then produced GDP lags behind potential GDP about $2-3 \%$. Coefficient 2 is determined empirically and for each country is different. This difference is in the interval 2-3 (Bikse, 2003; Adam etc., 1987).

In accordance with the Okun's Law, the unmanufactured GDP as a result of the impact of unemployment, is calculated as a percentage of actual unemployment and percentage of natural unemployment in the country and the difference between these indicators are multiplied by 2 (in the range of $2-3 \%$ ). The size shall be multiplied by the annual potential GDP (Bikse, 2003).

Okun's Law can be expressed in the form that reflects the relationship between GDP and unemployment dynamics. If the actual unemployment rate against the previous year's unemployment level remains constant, then real gross domestic product will increase by $3 \%$ per year. Such increment rate of GDP growth is ensured by population growth, capital accumulation, and scientific and technical progress (Bikse, 2003).

Arthur Okun has discovered the relationship between GDP and unemployment dynamics, as reflected in the formula:

$$
\frac{Y_{t}-Y_{t-1}}{Y_{t-1}} 100=3-2\left(u_{t}-u_{t-1}\right)
$$

After which:

$\mathrm{Y}_{\mathrm{t}}$ - The actual production volume in a given year,

$\mathrm{Y}_{\mathrm{t}-1}$ - The actual production volume for the previous year,

$\mathrm{u}_{\mathrm{t}}$ - The actual unemployment rate in a given year, $\mathrm{u}_{\mathrm{t}-1}-$ The actual unemployment rate in the previous year (Bikse, 2003).

Calculation of youth unemployment economic losses

To calculate the economic costs of youth unemployment, there was defined the base year when Latvia reached the full employment of resources, i.e., the potential level of production. It takes into account the year 2007 when the real GDP was 22'557.0 million EUR and full employment was reached.

According to calculations, the average annual real GDP (GDP calculation used 2010 constant prices) growth should reach 3\% (the calculation used a 3\% rate) (Bikse, 2005; Bikse, 2015).

There was a calculated potential GDP in 2008 2015, for example, in 2013 compared with 2007, the potential GDP should increase by $19.41 \%$ and in 2015 compared with 2007 it should increase by $26.67 \%$.

Using the data from the Central Statistical Bureau of Latvia, the overall unemployment rate from 2008 - 2015 in Latvia was calculated as the difference between the actual and the natural unemployment rate.

For example, in 2013 the real unemployment rate was $11.9 \%$.

Natural unemployment (an assumed rate) was $6 \%$, based on the real GDP.

The difference between the real unemployment rate and the natural rate of unemployment:

$11.9 \%-6 \%=5.9 \%$

The lost GDP due to unemployment: $5.9 \% * 2 \%=$ $11.8 \%$

The lost GDP due to unemployment was calculated $(11.8 \% *$ potential GDP), which was $11.8 \% *$ EUR 26934.23 million $=$ EUR 3172.85 million.

Finally, there was calculated the proportion of unemployed young people (from 15 to 24 years old) in 2013, which was $17.9 \%$ (according to data of the Central Statistical Bureau of Latvia). The calculation assumed that youth contribution to the growth of GDP was not different from adult's contribution.

It was calculated what part of the GDP was not produced by youth. 


\section{Calculated data on the lost GDP due to youth unemployment from}

\section{8 to 2015}

\begin{tabular}{|l|c|c|c|c|c|c|c|}
\hline Year & $\begin{array}{c}\text { Proportion of } \\
\text { unemployed } \\
\text { youth (from } \\
\mathbf{1 5} \text { to 24 years } \\
\text { old), \% }\end{array}$ & $\begin{array}{c}\text { Potential } \\
\text { GDP with } \\
\text { 3\% growth } \\
\text { per year, } \\
\text { million EUR }\end{array}$ & $\begin{array}{c}\text { Potential } \\
\text { GDP } \\
\text { growth } \\
\text { from } \\
\mathbf{2 0 0 7} \%\end{array}$ & $\begin{array}{c}\text { GDP } \\
\text { growth } \\
\text { from 2007, } \\
\text { million } \\
\text { EUR }\end{array}$ & $\begin{array}{c}\text { Lost GDP due } \\
\text { to unemploy- } \\
\text { ment, million } \\
\text { EUR }\end{array}$ & $\begin{array}{c}\text { Lost GDP } \\
\text { due to youth } \\
\text { unemploy- } \\
\text { ment, million } \\
\text { EUR }\end{array}$ & $\begin{array}{c}\text { Lost GDP } \\
\text { due to youth } \\
\text { unemploy-ment } \\
\text { compared with } \\
\text { potential GDP, } \\
\text { \% }\end{array}$ \\
\hline $\mathbf{2 0 0 7}$ & - & 22557.00 & - & - & - & - & - \\
\hline $\mathbf{2 0 0 8}$ & 22 & 23233.71 & 3.00 & 676.71 & 1758.79 & 386.93 & 1.67 \\
\hline $\mathbf{2 0 0 9}$ & 22.6 & 23930.72 & 5.91 & 1373.72 & 4159.16 & 939.97 & 3.93 \\
\hline $\mathbf{2 0 1 0}$ & 20.6 & 24648.64 & 8.74 & 2091.64 & 4776.91 & 984.04 & 3.99 \\
\hline $\mathbf{2 0 1 1}$ & 19.1 & 25388.10 & 11.49 & 2831.10 & 4082.41 & 779.74 & 3.07 \\
\hline $\mathbf{2 0 1 2}$ & 18.6 & 26149.75 & 14.15 & 3592.75 & 3891.08 & 723.74 & 2.77 \\
\hline $\mathbf{2 0 1 3}$ & 17.9 & 26934.24 & 19.41 & 4377.24 & 3172.85 & 567.94 & 2.11 \\
\hline $\mathbf{2 0 1 4}$ & 15.7 & 27742.26 & 22.99 & 5185.26 & 2962.87 & 465.17 & 1.68 \\
\hline $\mathbf{2 0 1 5}$ & 13.8 & 28574.53 & 26.68 & 6017.53 & 2794.59 & 385.65 & 1.35 \\
\hline
\end{tabular}

Source: authors' construction based on data from the Central Statistical Bureau of Latvia.

For example, in 2013 the lost GDP due to youth unemployment was EUR 567.94 million, which was $11.2 \%$ of the potential GDP in 2013 (see Table 1).

As shown in Table 5, according to the above mentioned methodology, the greatest lost GDP due to youth unemployment was in 2010 - EUR 984.04 million and in 2009 - EUR 939.97 million.

In 2014, the lost GDP due to youth unemployment was estimated at EUR 465.17 million, and in 2015 it was smaller - EUR 385.65 million.

\section{Conclusions}

Youth unemployment has a negative impact on youth development, health and professional career as well as on economic growth, productivity, the gross domestic product, and it increases economic costs for state, because there is more money to be paid on social benefits and less money coming in from taxes.

Based on the theoretical base, losses from unemployed youth were calculated as the lost GDP of Latvia from 2008 to 2015 . The losses in the above mentioned period were estimated at EUR 5233.18 billion.

Higher losses from youth unemployment were in 2010 - 990.14 million EUR and in 2009 - 946.46 million EUR.

In 2014 losses from youth unemployment decreased to 470.40 million EUR and in 2015 to 390.39 million EUR.

\section{Acknowledgements}

The preparation of the paper was supported by the National Research Program 5.2. Economic Transformation, Smart Growth, Governance and Legal Framework for the State and Society for Sustainable Development - a New Approach to the Creation of a Sustainable Learning Community, Project EKOSOCLV.

\section{References}

1. Adam, C., Fenton, P.R., \& Larsen, F. (1987). Potential Output in Major Industrial Countries. In: World Economic and Financial Surveys, Staff Studies for the World Economic Outlook, The Research Department of the International Monetary Fund, pp. $1-14$.

2. Augsts bezdarbs Latvijā-nolemtība vai izvēle?(High Unemployment in Latvia-Fatality or Choice?) (2010). A/S Swedbank. Retrieved February 5, 2017, from: https://www.swedbank.lv/files/analitiskie_materiali/ swedbank_petijums/Swedbank_Petijums_2010_12_LV.pdf. (in Latvian).

3. Balan, M. (2014). Analysis of Unemployment among Young Individuals from Romania by Econometric Methods. In: International Auditing \& Risk Management, No. 3 (35), pp. 90 - 97.

4. Bezdarbnieki pa vecuma grupām un dzimuma (Unemployed by Age Group and Sex) (2017). Retrieved February 13, 2017, from: http://data.csb.gov.lv/pxweb/lv/Sociala/Sociala_ikgad_nodarb/NB0250. px/?rxid=cdcb978c-22b0-416a-aacc-aa650d3e2ce0 (in Latvian). 
5. Bikse, V. (2003). Makroekonomika (Macroeconomics). Tālmācības kurss. Rīga: SIA 'Izglītības soḷ'. 314 lpp. (in Latvian).

6. Bikse, V. (2005). Ekonomikas attīstības problēmas mūsdienās (Contemporary Problems of Economic Development). No: Latvijas Universitātes raksti Vadības zinātnē, 690. sējums, 160. - 174. 1pp. (in Latvian).

7. Bikse, V. (2015) Makroekonomika: teorija un politika (Macroeconomics: Theory and Policy). Liepāja: Liepājas Universitāte, iespiests 'LiepU LiePA tipogrāfijā', 69. - 91. lpp. (in Latvian).

8. Dao, M., \& Loungani, P. (2010). The Human Cost of Recessions: Assessing it, Reducing it. IMF Staff Position note SPN/10/17.

9. Fares, J., \& Tiongson, E.R. (2007). Youth Unemployment, Labour Market Transitions, and Scarring: Evidence from Bosnia and Herzegovina. In: Policy, Research Working Paper, No. WPS 4183, Vol. 1.

10. Global Employment Trends for Youth 2010 (2010). International Labour Organisation, Geneva: ILO. Retrieved February 5, 2017, from: http://www.ilo.org/wcmsp5/groups/public/---ed_emp/---emp_elm/--trends/documents/publication/wcms_143349.pdf.

11. Grinevica, L., Rivza, B., \& Rivza, P. (2016). Scenarious for Reducing Youth Unemployment and Promoting Sustainability in the Regions of Latvia. In: Journal of Security and Sustainability Issues, Vol.5., No. 3., ISSN 2029-7017 print/ ISSN 2029-7025 online, pp. 437 - 449.

12. Hjūza, D., \& Borbējs- Pece, T.B., (2012). Jauniešu bezdarbs: mūslaiku krīze (Youth Unemployment: The Contemporary Crisis). Mūžilga karjeras atbalsta rīcībpolitikas nozīme darba piedāvājuma un pieprasījuma jomā, Eiropas mūžilga karjeras atbalsta politikas tīkls, 20 lpp. (in Latvian).

13. Iekšzemes kopprodukts Latvijā kopā (EKS-95) (Gross Domestic Product in Latvia, total (ESA-95)) (2015). Retrieved February 5, 2017, from: http://www.csb.gov.lv/statistikas-temas/metodologija/iekszemeskopprodukts-latvija-kopa-eks-95-34403.html. (in Latvian).

14. Keep, E. (2012). Youth Transitions, the Labour Market and Entry into Employment: Some Reflections and Questions. In: SKOPE, Cardiff University, Research Paper No. 108, p. 39.

15. Komisijas pazinojums Eiropas Parlamentam, Padomei, Eiropas Ekonomikas un sociālo lietu komitejai un regionu komitejai. Jauniešu pāreja uz nodarbinātību (Communication from the Commission to the European Parliament, the Council, the European Economic and Social Committee and the Committee of the Regions. Youth Transition to Employment) (2012). Retrieved April 1, 2016, from: http://ec.europa.eu/ transparency/regdoc/rep/1/2012/LV/1-2012-727-LV-F1-1.Pdf. (in Latvian).

16. Novak, M., \& Darmo, L. (2015). The Youth Unemployment in the European Area. In: SGEM 2015 International Multidisciplinary Scientific Conference on Social Sciences and Arts, Section Economics and Tourism, pp. $963-970$.

17. Salvador, R.G., \& Leiner-Killinger, R. (2008). An Analysis of Youth Unemployment in the Euro Area. In: ECB Occasional Paper, No. 89. pp. $1-45$.

18. O’Higgins, N. (2001). Youth Unemployment and Employment Policy: A Global Perspective. In: MPRAMunich Personal RePEc Archive, paper No. 23698, International Labour Office, ISBN 92-2-111348-1, p. 244.

19. Unemployment Statistics (2017). Retrieved July 21, 2017, from: http://ec.europa.eu/eurostat/statisticsexplained/index.php/Unemployment_statistics.

20. Youth Unemployment: the Crisis We Cannot Afford (2012). The ACEVO Commission on Youth Unemployment, p. 128.

21. Youth Unemployment in Latvia in 2016 Highest in Baltics (2017). Retrieved July 21, 2017, from: http:// www.baltic-course.com/eng/analytics/?doc $=129359$. 